\title{
Gingival melanin de-pigmentation for aesthetic correction
}

\author{
Lisa Neelathil Chacko, ${ }^{1}$ Sathish Abraham²
}

${ }^{1}$ Department of Periodontics, S.M.B.T. Dental College \& Hospital, Tal. Sangamner, Maharashtra, India

${ }^{2}$ Department of Conservative Dentistry and Endodontics,

S.M.B.T. Dental College \& Hospital, Tal. Sangamner, Maharashtra, India

Correspondence to Dr Sathish Abraham, abrahamsathish@yahoo.in

Accepted 8 June 2014
CrossMark

To cite: Chacko $L N$ Abraham S. BMJ Case Rep Published online: [please include Day Month Year] doi:10.1136/bcr-2014205711

\section{DESCRIPTION}

Pigmentation due to melanin is normal and physiological. However, it can be present in cases of hyper-plastic benign lesions such as lentigo and freckles (ephelides). It is also seen in benign proliferation of melanocytes (nevi), melanotic macules and certain neoplastic lesion melanomas. Melanin is a derivative of tyrosine which is a polymer composed of polyacetylene, polypyrrole and polyalanine. It is responsible for the normal physiological pigmentation in the oral cavity. It is commonly seen on the gingiva, mucosa, hard palate and tongue. It can be diffuse or irregular (mottled or macular) in shape with different shades of colour ranging from light brown, dark brown to black. ${ }^{1}$ Extensive gingival pigmentation can pose serious aesthetic concerns among the affected which may lead to low self-esteem and confidence.

Patients and the general public have now become more aesthetically conscious. This may be attributed to continuing education about oral healthcare and its benefits through various media. However, the patients who present with aesthetic problems due to gingival pigmentation may be treated with various de-pigmentation techniques by dental surgeons. The different strategies or treatment modalities include conventional surgical correction, bur abrasion, laser, cryosurgery and electro-surgery. These modalities should be applicable only when patients report about discoloured gingiva, which can be visible and disturbing during speech or while smiling (gummy smile), and seek an aesthetic correction. $^{2}$

A 25 -year-old man presented with dark and disturbing discolouration of the gingiva (figure 1). After thorough clinical and systemic evaluation, de-pigmentation with split mouth technique was opted for. The maxillary arch was de-pigmented using the conventional scalpel method (figure 2). This technique was used adopting an earlier and still popular technique for removal of undesirable pigmentation: using slicing technique with a scalpel. By removing the gingival epithelium along with a layer of underlying connective tissue (allowing the denuded connective tissue to heal by secondary intention), the observed surgical de-pigmentation may be achieved. Studies have suggested that this technique is still the best option with many advantages such as a longer term postoperative aesthetic phase, cost-effectiveness, patient acceptability and affordability. The mandibular arch in our patient was de-pigmented using a super pulsed $\mathrm{CO}_{2}$ laser (figure 3). The $\mathrm{CO}_{2}$ laser was used at $10 \mathrm{~W}, 0.8 \mathrm{~mm}$ spot size with $20 \mathrm{~Hz}$ in $10 \mathrm{~ms}$. It was performed on a subsequent visit 2 weeks after the scalpel procedure. Lasers are known to have advantages such as being less invasive, more convenient and having a clean work field with less haemorrhage. ${ }^{3}$ However, disadvantages include the cost factor, specialised training requirement of the operator and also patient acceptability. Postoperative pain was comparatively

Figure 1 Preoperative photograph showing extensive melanin pigmentation and postoperative photograph (8 months).

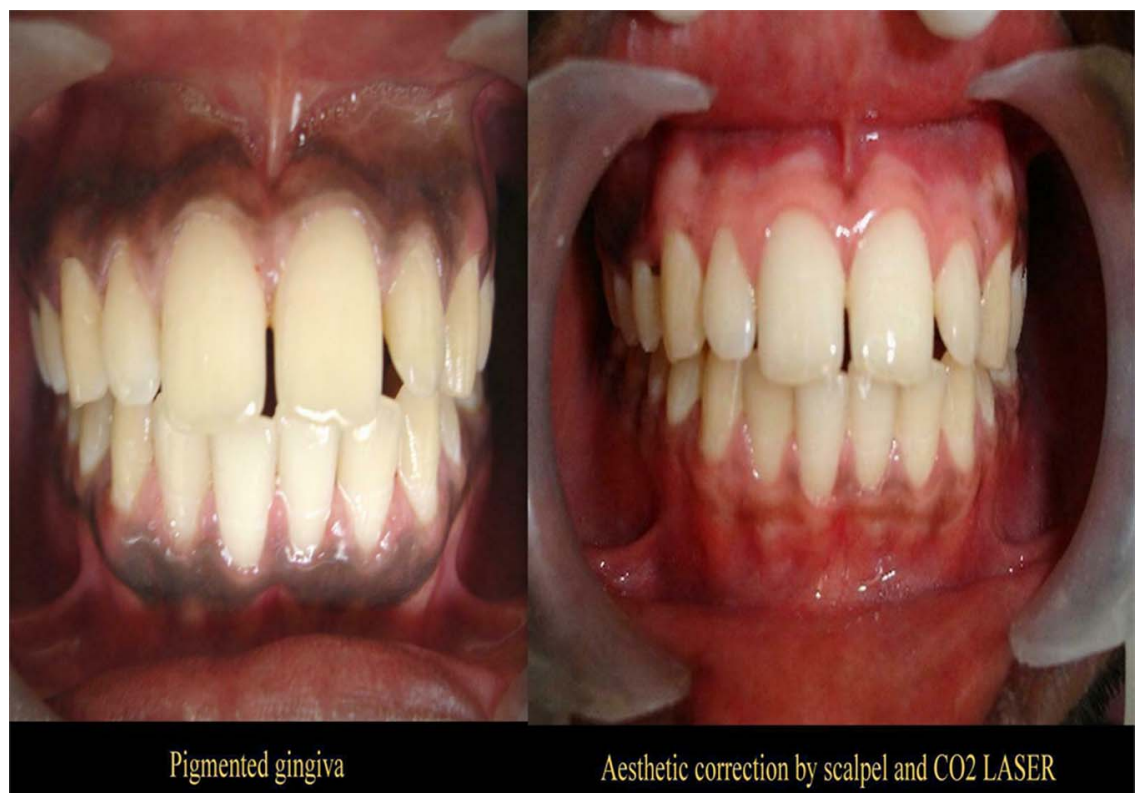




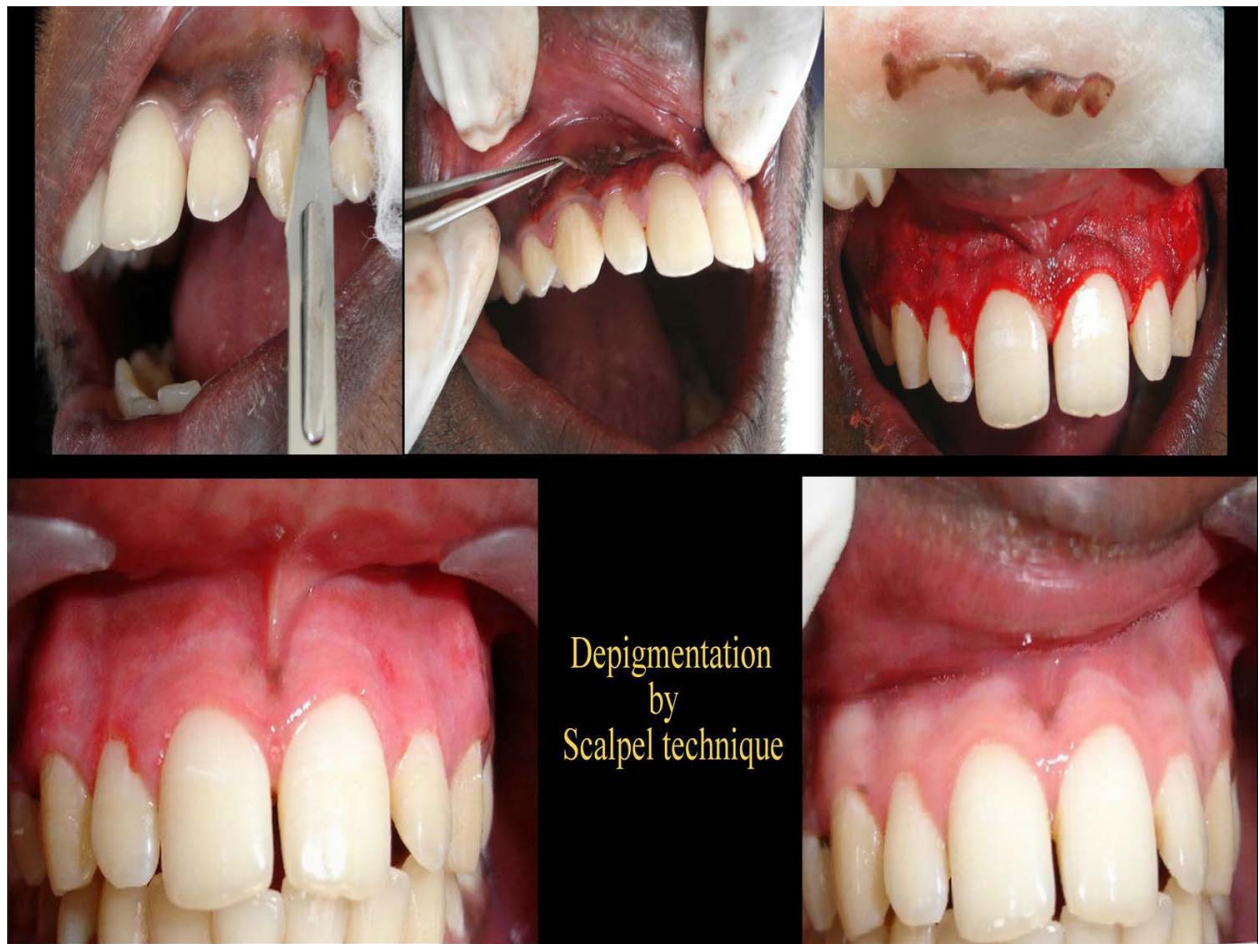

Figure 2 Surgical de-pigmentation by a scalpel technique with 2 weeks and 8 months postoperative photographs.

more in the conventional scalpel technique. A periodontal dressing was placed for 10 days to cover the healing phase. Postoperative discomfort was minimal in the mandibular arch where the $\mathrm{CO}_{2}$ laser was used. The healing phase was normal and uneventful in both the arches.

Postoperative follow-up of 8 months suggesed that the scalpel technique used in the maxillary arch was more effective in this patient than the $\mathrm{CO}_{2}$ laser technique used in the mandibular arch (figure 1). Annals suggest that the re-pigmentation possibilities range from as early as 1 month to over 7 years and may vary in populations and gender. However, it has been suggested that the mechanism of re-pigmentation occurs by migration of melanocytes into the de-pigmented areas. ${ }^{4} \mathrm{~A}$ deeper study may be required to note the re-pigmentation patterns in the oral cavity.

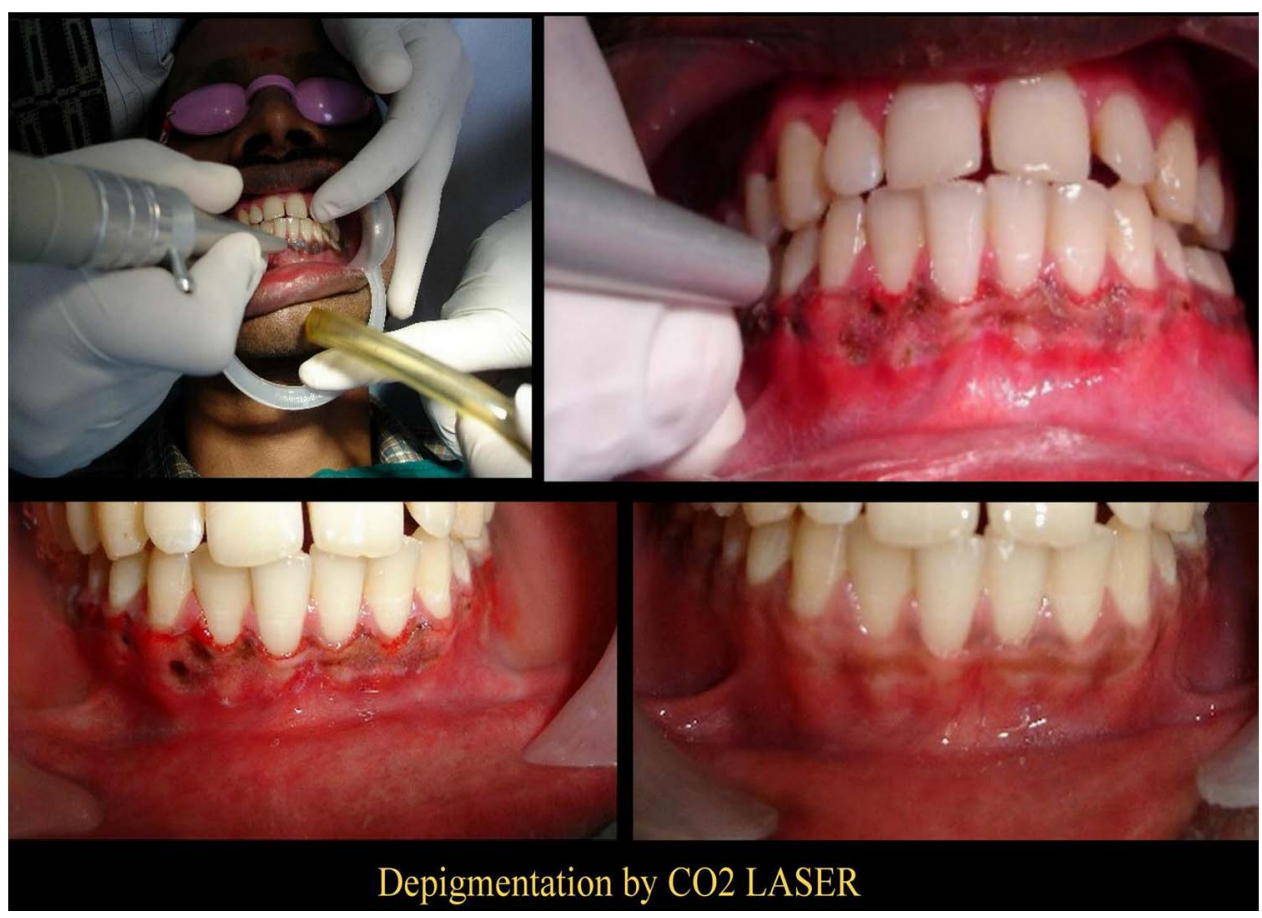

Figure 3 De-pigmentation using a $\mathrm{CO}_{2}$ laser with 2 weeks and 8 months postoperative photographs. 


\section{Learning points}

- De-pigmentation is an accepted treatment strategy for aesthetic correction and should only be performed if requested by the patient.

- Surgical de-epithelialisation is still considered the best option to achieve better results.

- A repeat procedure is the only method in cases of recurrence.

Competing interests None.
Patient consent Obtained.

Provenance and peer review Not commissioned; externally peer reviewed.

\section{REFERENCES}

1 Karydis A, Bland P, Shiloah J. Management of oral melanin pigmentation. J Tennessee Dent Assoc 1992;2:10-15.

2 Lin YH, Tu YK, Lu CT, et al. Systematic review of treatment modalities for gingival depigmentation: a random-effects Poisson regression analysis. J Esthetic Restor Dent 2014;26:162-78.

3 Esen $\mathrm{E}$, Haytac $\mathrm{MC}, \mathrm{Oz} I \mathrm{~A}$, et al. Gingival melanin pigmentation and its treatment with the $\mathrm{CO}_{2}$ laser. Oral Surg Oral Med Oral Pathol Oral Radiol Endod 2004;98:522-7.

4 Kathariya R, Pradeep AR. Split mouth de-epithelization techniques for gingival depigmentation: a case series and review of literature. I Indian Soc Periodontol 2011;15:161-8.

Copyright 2014 BMJ Publishing Group. All rights reserved. For permission to reuse any of this content visit http://group.bmj.com/group/rights-licensing/permissions.

BMJ Case Report Fellows may re-use this article for personal use and teaching without any further permission.

Become a Fellow of BMJ Case Reports today and you can:

- Submit as many cases as you like

- Enjoy fast sympathetic peer review and rapid publication of accepted articles

- Access all the published articles

- Re-use any of the published material for personal use and teaching without further permission

For information on Institutional Fellowships contact consortiasales@bmjgroup.com

Visit casereports.bmj.com for more articles like this and to become a Fellow 